\title{
HUBUNGAN KUALITAS PELAYANAN KADER DENGAN KEPATUHAN KUNJUNGAN IBU BALITA KE POSYANDU DI DESA GASARIBU KECAMATAN LAGUBOTI KABUPATEN TOBA SAMOSIR
}

\author{
Erita Saragih, Dosmaida Nababan, Maria Sihombing \\ Program Studi D3 Keperawatan, STIKes Arjuna \\ E-mail: eritasaragih1212@gmail.com
}

\begin{abstract}
The health system can function optimally if supported by empowering people and as a form of empowerment is their guidance Posyandu cadre and mothers who bring their babies to Posyandu. Guidance cadres would improve their knowledge so that changing the behavior for implementation of knowledge. The purpose of this study was to analyze the relationship between service quality and compliance cadres with a visit to Posyandu toddler's mother in the village of Gasaribu District of Laguboti Toba Samosir. The study design used is cross sectional. The population mothers with toddlers were registered in the region of in the village of Gasaribu District of Laguboti Toba Samosir with a sample size of 50 respondents. Independent variable is the quality of service cadre, while the dependent variable is the compliance visit to the Posyandu toddler's mother. Measuring instrument uses closed questionnaire to measure guidance and registers Posyandu cadres Posyandu to measure compliance visit to the Posyandu toddler's mother. Data were analyzed with chi square test Results: There was a significant correlation between the quality of service cadres with compliance visits mothers $(p=0.005)$. Posyandu already actively supported also by the mother's educational background is sufficient. Guidance given Posyandu cadres can encourage mothers to come to Posyandu. The cadre who has worked with both fast and precise, and further enhance its services, especially in the field of service quality cadres.
\end{abstract}

Keywords: Quality of service cadre, compliance visits

\begin{abstract}
Abstrak
Sistem kesehatan dapat berfungsi secara optimal jika didukung dengan pemberdayaan masyarakat dan sebagai bentuk pemberdayaan adalah bimbingan kader Posyandu dan ibu-ibu yang membawa bayi mereka ke Posyandu. Bimbingan kader akan meningkatkan pengetahuan mereka sehingga mengubah perilaku untuk implementasi pengetahuan. Tujuan dari penelitian ini adalah untuk menganalisis hubungan antara kualitas layanan dan kader kepatuhan dengan kunjungan ibu balita Posyandu di desa Gasaribu Kecamatan Laguboti Toba Samosir. Desain penelitian yang digunakan adalah cross sectional. Populasi ibu dengan balita terdaftar di wilayah Desa Gasaribu Kecamatan Laguboti Toba Samosir dengan jumlah sampel 50 responden. Variabel bebas adalah kualitas kader layanan, sedangkan variabel terikat adalah kunjungan kepatuhan kepada ibu balita Posyandu. Alat ukur menggunakan kuesioner tertutup untuk mengukur pedoman dan catatn kader Posyandu untuk mengukur kunjungan kepatuhan kepada ibu balita ke Posyandu. Data dianalisis dengan uji chi square. Ditemukan ada hubungan yang signifikan antara kualitas kader layanan dengan kepatuhan kunjungan ibu $(\mathrm{p}=0,005)$. Posyandu sudah aktif didukung pula oleh latar belakang pendidikan ibu yang memadai. Bimbingan yang diberikan kader Posyandu dapat mendorong ibu untuk datang ke Posyandu. Para kader yang telah bekerja dengan cepat dan tepat, dan lebih meningkatkan layanannya, terutama di bidang kader kualitas layanan.
\end{abstract}

Kata Kunci : Kualitas kader layanan, kunjungan kepatuhan 


\section{PENDAHULUAN}

Posyandu merupakan wadah untuk mendapatkan pelayanan dasar terutama dalam bidang kesehatan dan keluarga berencana yang dikelola oleh masyarakat. Pelayanan kesehatan dasar di Posyandu meliputi KIA (Kesehatan Ibu dan Anak), KB (Keluarga Berencana), imunisasi, gizi, dan penanggulangan diare. Masyarakat masih lebih banyak sebagai objek dari pada sebagai subjek pembangunan kesehatan (Depkes RI, 2009). Posyandu merupakan bentuk kegiatan pemberdayaan masyarakat yang mempunyai manfaat memperoleh informasi pelayanan kesehatan terutama kesehatan anak balita dan ibu, memantau pertumbuhan anak balita sehingga tidak terkena gizi buruk, memperoleh kapsul vitamin $\mathrm{A}$, dan untuk penyuluhan kesehatan mengenai kesehatan ibu dan anak (Kemenkes, 2015). Kegiatan Posyandu dilakukan setiap bulan dengan sasaran bayi/ balita umur 0-5 tahun untuk mengetahui status gizi balita dengan menggunakan Kartu Menuju Sehat (KMS). Penilaian pertumbuhan dan perkembangan balita dilakukan karena mereka termasuk umur yang beresiko terhadap permasalahan kesehatan terutama permasalahan kekurangan gizi (Ismawati, 2010).

Berdasarkan data Kementerian kesehatan Republik Indonesia (2015-2019), laporan target penimbangan posyandu di Indonesia pada tahun 2013 cakupan penimbangan balita di posyandu sebesar $80,3 \%$ dengan target sebesar $80 \%$, ini menunjukkan bahwa cakupan penimbangan balita tercapai. Pada tahun 2014 cakupan penimbangan sebesar 80,8\% menunjukkan adanya peningkatan dari tahun sebelumnya. Namun, capaian ini tidak memenuhi target yang ditetapkan yakni 85\%. Pada Tahun 2015 cakupan (D/S) belum mencapai target bahkan mengalami penurunan yakni sebesar $73 \%$ dengan target $87 \%$. Pemanfaatan sarana pelayanan kesehatan berbasis masyarakat secara optimal oleh masyarakat seperti pusat pelayanan terpadu atau posyandu merupakan salah satu pendekatan dan pelayanan kesehatan dasar ditingkat masyarakat yang berguna untuk menemukan dan mengatasi masalah yang terkait dengan kesehatan bayi dan balita. (Depkes RI, 2009).

Mempercepat penurunan angka kematian ibu dan anak, meningkatkan pelayanan kesehatan ibu untuk menurunkan Incident Mortality Rate (IMR), mempercepat penerimaan NKKBS, meningkatkan kemampuan masyarakat untuk mengembangkan kegiatan kesehatan, dan kegiatan lainnya yang menunjang peningkatan kemampuan hidup masyarakat yang merupakan tujuan dari posyandu (Mubarak dan Cahyatin, 2009). Berdasarkan hal tersebut diharapkan masyarakat ikut berperan serta dalam pencapaian derajat kesehatan sebaik - baiknya. Semua manusia mempunyai hak asasi untuk menentukan standar kehidupan yang adekuat bagi kesehatan dan kesejahteraan keluarganya termasuk sandang, pangan, papan, pelayanan kesehatan dan sosial yang mendapat jaminan ketika tidak mempunyai pekerjaan, mengalami sakit, ketidak mampuan, menjadi janda, lansia atau kekurangan lainnya dalam kehidupan di lingkungannya. Untuk mencapai apa yang menjadi hak tersebut seseorang akan termotivasi untuk memenuhi haknya, dimana hal ini tidak terlepas dari naluri manusia yang sangat kuat guna memenuhi sagala kebutuhan fisik maupun psikologisnya. Dalam hal ini peran serta masyarakat dalam mengelola dan memanfaatkan posyandu sangat diharapkan agar dapat menigkatkan derajat kesehatan masyarakat itu sendiri. Motivasi seseorang merupakan kekuatan dasar yang terdapat pada diri seseorang sehingga ia mau bertindak atau berbuat agar tercapai keseimbangan dalam dirinya. Posyandu merupakan kegiatan masyarakat terutama oleh ibu, dalam menjaga kelestarian hidup serta tumbuh kembang anak dan keluarga dengan bantuan lembaga ahli teknologi yang disediakan oleh pemerintah. (Ahmadi, 2009). Berdasarkan data dari Departemen Kesehatan Sumatera Utara, (2009) hingga tahun 2013 jumlah posyandu di Indonesia yang tersebar di 33 propinsi sekitar 330.000 unit posyandu, jumlah di Sumatera Utara 14.750 unit dengan jumlah sasaran balita 
sebanyak 1.571.162 jiwa. Jumlah posyandu di kota Medan sebanyak 1.406 unit yang mencakup sekitar 70\% lingkungan dari sekitr 2000 lingkungan yang ada di kota Medan.

Beberapa kendala yang dihadapi terkait dengan kunjungan balita ke posyandu salah satunya adalah tingkat pemahaman keluarga terhadap manfaat posyandu. Hal itu akan berpengaruh pada keaktifan ibu dalam mengunjungi setiap kegiatan posyandu. Karena salah satu tujuan posyandu adalah memantau peningkatan status gizi terutama pada balita, sehingga agar tercapai itu semua Beberapa kendala yang dihadapi terkait dengan kunjungan balita ke posyandu salah satunya adalah tingkat pemahaman keluarga terhadap manfaat posyandu. Hal itu akan berpengaruh pada keaktifan ibu dalam mengunjungi setiap kegiatan posyandu. Karena salah satu tujuan posyandu adalah memantau peningkatan status gizi terutama pada balita, sehingga agar tercapai itu

Masalah kesehatan tetap menjadi potensial terutama pada balita karena pada umur tersebut anak mengalami pertumbuhan yang pesat dan termasuk kelompok yang rentan gizi. Hasil Riskesdas (Riset Kesehatan Dasar) tahun 2007 menunjukan secara nasional cakupan penimbangan balita di posyandu sebesar $74,5 \%$. Begitu juga di Desa Gasaribu, Kecamatan Laguboti Toba Samsosir berdasarkan pencatatan kader angka rata-rata $\mathrm{D} / \mathrm{S}$ dalam tiap bulan tahun 2017-2018 mencapai 65\%. Laporan ini menunjukkan kunjungan balita rata-rata dalam tiap bulan di Desa Gasaribu masih di bawah target. Hal ini menunjukkan bahwa kemungkinan masyarakat kurang patuh membawa anak balitanya ke posyandu. Ketidakpatuhan kunjungan balita dalam tiap bulan menunjukkan peran serta masyarakat yang masih rendah.

Bagi masyarakat, penimbangan bulanan bukan merupakan kebutuhan utama yang harus dilaksanakan secara teratur. Beberapa hasil penelitian mengemukakan bahwa terdapat banyak faktor ibu tidak membawa anak balitanya ke posyandu. Hasil penelitian Fitrianto, B.G. (2015). mengemukakan bahwa adanya pemberdayaan kader dapat memberikan bimbingan dan pembinaan untuk meningkatkan peringkat status gizi. Hasil penelitian dari Widiastuti (2011) menyatakan bahwa pemanfaatan penimbangan balita di Posyandu di pengaruhi oleh pengetahuan kader, motivasi kader, dan faktor pekerjaan ibu balita. Menurut Riskesdas (Riset Kesehatan Dasar) tahun 2007 menunjukkan bahwa alasan utama rumah tangga tidak memanfaatkan posyandu karena pelayanannya tidak lengkap $(49,6 \%)$, lokasinya jauh (26\%), dan tidak tersedianya posyandu (24\%).

Ketidakpatuhan kunjungan ke posyandu mengakibatkan ibu tidak akan memperoleh informasi dini mengenai kesehatan anak balitanya sehingga tidak ada dorongan untuk memperbaiki status gizi anak dan pemeliharaan kesehatan anak (Hardiana, M.P. (2014). Kedatangan mereka sangat penting untuk mengetahui pertumbuhan dan perkembangan anak dengan menggunakan Kartu Menuju Sehat (KMS) melalui penimbangan bulanan balita dan mengetahui keadaan kesehatan serta memberikan pelayanan kesehatan lainnya pada balita. Dengan adanya pemantauan dari KMS dapat meminimalkan terjadinya gizi buruk dan balita berat badannya di bawah garis merah (BGM).

Untuk meningkatkan kepatuhan kunjungan ibu balita ke Posyandu dalam peningkatan program kesehatan di Posyandu dapat dilakukan dengan meningkatkan fasilitas pelayanan di Posyandu, kader dan petugas kesehatan memberikan bimbingan dan pembinaan kepada ibu yang mempunyai balita, dan kerjasama antar petugas kesehatan dalam meningkatkan kegiatan di Posyandu secara terus menerus. Salah satu fasilitas tersebut adalah berupa KMS dimana semua ibu yang mempunyai balita memerlukan KMS, sedangkan bimbingan dapat diberikan oleh kader secara terjadwal dengan materi yang jelas dan mudah dipahami. Penelitian Sari, N pada tahun 2015 meneliti tentang pemberdayaan kader posyandu dalam upaya meningkatkan kualitas program gizi, menunjukkan bahwa adanya pemberdayaan 
tersebut terjadi peningkatan pengetahuan kader sehingga kader mampu melakukan bimbingan kepada Ibu Balita di Posyandu. Bimbingan tersebut dapat meningkatkan partisipasi masyarakat dalam pencapaian pengetahuan kader, motivasi kader, dan faktor pekerjaan ibu balita berhubungan positif dengan tingkat pemanfaatan penimbangan balita di Posyandu. Ini berarti pengetahuan kader berperan pada partisipasi masyarakat. Berdasarkan data tersebut, maka saya tertarik untuk meneliti hubungan hubungan antara kualitas pelayanan kader dengan kepatuhan kunjungan ibu balita ke Posyandu di desa Gasaribu Kecamatan Laguboti Kabupaten Toba Samosir.

\section{Posyandu}

Posyandu adalah salah satu bentuk Upaya Kesehatan Bersumber Daya Masyarakat (UKBM) yang dikelola dan diselenggarakan dari, oleh, untuk dan bersama masyarakat dalam penyelenggaraan pembangunan kesehatan, guna memberdayakan masyarakat dalam memperoleh pelayanan kesehatan dasar untuk mempercepat penurunan angka kematian ibu dan bayi (Depkes RI, 2011).

Tujuan umum posyandu adalah menunjang percepatan penurunan Angka Kematian Anak Balita (AKABA) di Indonesia melalui upaya pemberdayaan masyarakat. Sasaran Posyandu adalah seluruh masyarakat/keluarga utamanya adalah bayi baru lahir, balita, ibu hamil, ibu menyusui, Pasangan Usia Subur (PUS) (Kemenkes RI. 2011)

\section{Kegiatan Posyandu}

Kegiatan utama posyandu seperti yang sudah dijelaskan noleh Kemenkes RI (2011) meliputi kegiatan pemantauan tumbuh kembang balita, pelayanan kesehatan dan anak seperti : imunisasi untk mencegah penyakit, penanggulangan diare, pelayanan $\mathrm{KB}$, penyuluhan dan konseling bila diperlukan.

\section{Pelayanan Posyandu}

\section{A. Persiapan Pelayanan Posyandu}

Sebelum pelaksanaan Posyandu, kader memastikan sasaran seperti jumlah bayi baru lahir, bayi, balita, ibu hamil, ibu menyusui, ibu nifas, dan pasangan usia subur. Langkahlangkah persiapan pelaksanaan posyandu $(\mathrm{H}-$

1) adalah :

1. Menyebarluaskan hari buka posyandu melalui pertemuan warga setempat. Kader dapat mengajak sasaran untuk datang ke posyandu dengan bantuan tokoh masyarakat atau tokoh agama setempat. Fasilitas umum seperti sarana ibadah dapat dimanfaatkan untuk menyebarluaskan informasi.

2. Mempersiapkan tempat pelaksanaan Posyandu

3. Mempersiapkan sarana Posyandu. Kebutuhan sarana berupa KMS/buku KIA, alat timbang (dacin dan sarung), pita LILA), obat gizi (kapsul vitamin A, tablet tambah darah,oralit), alat bantu penyuluhan, buku pencatatan dan pelaporan, dan lainnya

4. Mempersiapkan bahan makanan tambahan. Mempersiapkan bahan makanan tambahan dengan bahan yang diperoleh dari daerah setempat dan bergizi.

\section{Pelaksanaan Posyandu}

1. Pendaftaran Balita

a. Balita didaftar dalam pencatatan balita

b. Buku KMS/Buku KIA pada ibu. Untuk balita yang baru pertama kali ditimbang dan tidak mempunyai KMS/Buku KIA, berikan KMS sesuai jenis kelamin/Buku KIA. Isikolomnya secara lengkap, nama balita dicatat pada secarik kertas dan diselipkan pada KMS/Buku KIA. Bagi balita yang tidak mempunyai KMS/Buku KIA larena hilang, pencatatan sementara menggunakan SIP Posyandu

c. Ibu dipersilahkan membawa balita menuju tempat penimbangan

2. Pendaftaran Ibu Hamil. Ibu hamil didaftar dalam formulir catatan untuk ibu hamil, kemuadian dipersilahkan menuju ke 
tempat penimbangan dan pengukuran LILA.

3. Pendaftaran PUS. PUS didaftar dalam formulir catatan dan namanya ditulis di secarik kertas, kemudian langsung menuju ke tempat penyuluhan, dipersilahkan dilanjutkan dengan penapisan status imunisasi TT oleh petugas kesehatan.

4. Penimbangan. Mempersiapkan Dacin. Gantung dacin pada tempat yang kokoh seperti pelana rumah atau kusen pintu atau dahan pohon atau penyangga kaki tiga yang kuat. Letakkan bandul geser pada angka nol, jika ujung kedua paku timbang tidak dalam posisi lurus, maka timbangan perlu diganti dengan yang baru. Atur posisi angka pada batang dacin sejajar dengan mata penimbang. Pastikan bandul geser berada pada angka nol. Pasang sarung timbang/celana timbang/kotak timbang yang kosong pada dacin. Seimbangkan dacin yang telah dibebani dengan sarung timbang/celana timbang/kotak timbang dengan memberi kantung plastik berisikan pasir/batu di ujung batang dacin, sampai kedua jarum di atas tegak lurus.

5. Menimbang Balita. Masukkan balita ke dalam sarung timbang dengan pakaian seminimal mungkin dan geser bandul sampai jarum tegak lurus. Baca berat badan balita dengan melihat angka di ujung bandul geser. Catat hasil penimbangan dengan benar di kerats/buku bantu dalam $\mathrm{kg}$ dan ons. Kembalikan bandul ke angka nol dan keluarkan balita dari sarung/celana/kotak timbang.

6. Pengukuran LILA pada ibu hamil dan WUS. Gunakan pita LILA panjang bagian merah 23,5 cm. Bila tidak tersedia pita LILA gunakan pita jahit pakaian dengan ukuran yang sama $(23,5 \mathrm{~cm})$. Pengukuran dilakukan di bagian tengah antara bahu dan siku lengan kiri. Lengan harus dalam keadaan bebas. Artinya otot lengan tidak tegang. Alat ukur tidak kusut (permukaannya rata), tetapkan letak bahu dan letak siku tangan, tetapkan titik tengah lengan atas, caranya rentangkan pita dari bahu ke arah siku. Tentukan tengah-tengah lengan atas ibu, lingkarkan pita ukur tepat pada tengah-tengah lengan atas ibu. Bacalah skala secara benar. Bila masih berada di bagian merah maka ibu tersebut tergolong sangat kurus atau menderita kurang energi kronik.

\section{B. Pencatatan}

1. Balita

Pada penimbangan pertama isilah kolom identitas yang tersedia pada KMS/Buku KIA. Cantumkan bulan lahir dan bulan penimbangan anak. Pindahkan hasil penimbangan dari secarik kertas ke KMS. Letakkan titik berat badan dan buat garis pertumbuhan anak. Hubungkan titik berat badan bulan lalu dengan bulan ini.Catat setiap kejadian yang dialami anak. Isi kolom ASI, imunisasi, dan vitamin A bila diperlukan. Salin semua data dari KMS/Buku KIA pada SIP.

2. Ibu Hamil. Hasil penimbangan berat badan dan pengukuran LILA ibu hamil dicatat dalam Buku KIA dan register ibu hamil (SIP)

3. PUS/WUS. Hasil pengukuran LILA pada WUS dicatat pada register PUS/WUS

\section{Penyuluhan}

Penyuluhan dilakukan untuk perorangan dan dapat diperkaya untuk kelompok

1. Penyuluhan untuk Balita. Topik penyuluhan antara lain pemberian asi saja samapai anak berumur 6 bulan, pemberian MP ASI setelah anak berumur 6 bulan, melanjutkan pemberian ASI sampai anak berumur 2 tahun, imunisasi dasar lengkap pada bayi kurang dari satu tahun, pemberian vitamin A setiap bulan Februari dan Agustus pada bayi (6-12 bulan) dan balita (1-5 tahun), untuk pencegahan kebutaan dan menambah daya tahan tubuh anak, bahaya diare pada balita, bahaya infeksi saluran pernapasan akut, gejala demam pada balita, perawatan gigi dan mulut

2. Penyuluhan untuk Ibu Hamil. Topik penyuluhan adalah istirahat cukup, imunisasi tetanus toxoid, makan hidangan 
bergizi, tablet penambah darah, pengenalan tanda bahaya kehamilan, inisisasi menyusuidini, kolostrum ASI, dan perawatan kesehatan gigi dan mulut.

3. Penyuluhan untuk Ibu Nifasdan Ibu Menyusui. Topik penyuluhan antara lain anjuran ibu makan makanan yang bergizi 1 piring lebih banyak dari biasanya, anjuran ibu minum air putih paling sedikit 8 gelas setiap hari, Jika ASI sedikit, ibu dianjurkan konsultasi kepada petugas kesehatan, anjurkan ibu nifas segera ber$\mathrm{KB}$, anjurkan ibu minum 1 kapsul Vitamin A segera setelah melahirkan dan minum lagi pada hari kedua, ASI eksklusif, cara menyusui yang baik dan benar, ASI diberikan sesering mungkin,ASI diberikan sampai anak berumur 2 tahun.

4. Penyuluhan untuk PUS. Topik yang penting disampaikan adalah anjuran untuk ber $\mathrm{KB}$, menjaga jarak/mengatur kehamilan, menghindari 4 terlalu dan 3 terlambat, mnafaat imunisasi TT 5 dosis, memlihara kesehatan reproduksi, dan menjaga keharmonisan keluarga.

\section{METODE}

Jenis penelitian ini adalah dengan rancangan cross sectional yang bertujuan untuk menjelaskan bagaimana hubungan kualitas pelayanan kader dengan kepatuhan ibu membawa balita ke posyandu di desa Gasaribu Kecamatan Laguboti Kabupaten Toba Samosir dengan jumlah sampel sebanyak 50 orang dan menggunakan teknik probability sampling dengan Proportionate stratified random sampling. Pengambilan data dilakukan pada bulan Februari 2018 di Desa Gasaribu Kecamatan Laguboti. Metode pengumpulan data pada penelitian ini dilakukan dengan cara pembagian kuesioner. Kuesioner dibuat sendiri oleh peneliti yang telah diuji validitas dan reliabilitasnya. Analisa data dilakukan dengan menggunakan uji korelasi Pearson pada tingkat kepercayaan 95\%. Hak-hak responden dilindungi dari berbagai aspek dalam penelitian ini.
HASIL

Karakteristik Responden

\begin{tabular}{lcc}
\hline \multirow{1}{*}{ Usia } & Frekuensi & Persentase \\
\cline { 2 - 3 } & (Orang) & $(\%)$ \\
\hline$<25$ tahun & 2 & \\
26-35 tahun & 30 & 60 \\
36-45 tahun & 18 & 36 \\
\hline Jumlah & 50 & 100 \\
\hline IRT & 15 & 60 \\
Peg swasta & 15 & 30 \\
Peg Negri & 5 & 10 \\
\hline Jumlah & 50 & 100 \\
\hline SMA & 11 & 22 \\
D3 & 32 & 64 \\
Sarjana & 7 & 14 \\
\hline Jumlah & 50 & 100 \\
\hline
\end{tabular}

\section{Kualitas Pelayanan kader DI Gasaribu Kecamatan Laguboti}

Berdasarkan Kualitas pelayanan kader di posyandu di desa Gasaribu Kecamatan Laguboti Kabupaten Toba Samosir menunjukkan bahwa $100 \%$ kader memberikan kualitas pelayanan baik. Distribusi dapat dilihat pada tabel 2 dibawah ini.

\section{Distribusi Kualitas Pelayanan kader Posyandu}

\begin{tabular}{lcc}
\hline $\begin{array}{l}\text { Kualitas Pelayanan } \\
\text { Kader }\end{array}$ & $\begin{array}{c}\text { Frekuensi } \\
\text { (orang) }\end{array}$ & $\begin{array}{c}\text { Persentase } \\
(\%)\end{array}$ \\
\hline Pelayanan Baik & 50 orang & 100 \\
Pelayanan cukup & - & - \\
Pelayanan kurang & - & - \\
\hline \multicolumn{1}{c}{ Jumlah } & 50 & 100 \\
\hline
\end{tabular}

Kepatuhan ibu membawa balita ke posyandu

Kepatuhan ibu membawa balita ke posyandu di desa Gasaribu Kecamatan Laguboti Kabupaten Toba Samosir sebanyak 35 orang $(70 \%)$ patuh membawa balita ke Posyandu dan 15 orang (30\%) tidak patuh membawa balita ke Posyandu. 


\begin{tabular}{lcc}
\hline Kepatuhan ibu & Frekuensi & Persentase \\
\cline { 2 - 3 } & (Orang) & $\mathbf{( \% )}$ \\
\hline Patuh & 35 & 70 \\
Tidak patuh & 15 & 30 \\
\hline Jumlah & 50 & 100 \\
\hline
\end{tabular}

Hubungan Kualitas Pelayanan Dengan Kepatuhan Ibu Datang Ke Posyandu di Desa Gasaribu Kecamatan Laguboti Kabupaten Toba Samosir

Hubungan kualitas pelayanan dengan kepatuhan ibu datang ke Posyandu di Desa Gasaribu Kecamatan Laguboti Kabupaten Toba Samosir dengan hasil uji chi square dengan nilai $\mathrm{p}=0.005$ yang berarti ada Hubungan kualitas pelayanan dengan kepatuhan ibu datang ke Posyandu di Desa Gasaribu Kecamatan Laguboti Kabupaten Toba Samosir. Dengan nilai signifikansi 0.005 (<0.05), maka Ho ditolak yaitu ada Hubungan kualitas pelayanan dengan kepatuhan ibu datang ke Posyandu di Desa Gasaribu Kecamatan Laguboti Kabupaten Toba Samosir. Penelitian ini menggunakan tingkat kepercayaan 5\% dan kekuatan uji 95\%. Hasil uji Chi Square pada penelitian Hubungan kualitas pelayanan dengan kepatuhan ibu datang ke Posyandu di Desa Gasaribu Kecamatan Laguboti Kabupaten Toba Samosir

\section{PEMBAHASAN}

Kualitas Pelayanan kader Di Desa Gasaribu Kecematan Laguboti

Berdasarkan Kualitas pelayanan kader di posyandu di desa Gasaribu Kecamatan Laguboti Kabupaten Toba Samosir menunjukkan bahwa $100 \%$ kader memberikan kualitas pelayanan baik. Hal ini jelas tampak dalam defenisi yang dirumuskan oleh Goeth dan Davis yang dikutip Tjiptono (2012) bahwa kualitas merupakan suatu kondisi dinamis yang berhubugan dengan produk, jasa, manusia, proses, dan lingkungan yang memenuhi atau melebihi harapan. Sebaliknya, definisi kualitas yang bervariasi dari yang kontroversial hingga kepada yang lebih strategik. Asumsi peneliti kualitas pelayanan kader ini baik karena kader memahami fungsi dan peranan mereka sehingga mempengaruhi perilaku kader. Berdasarkan wawancara peneliti terhadap kader teryata kader posyandu seluruhnya mendapat bimbingan aktif dari kader posyandu.

Pada penelitian ini, bimbingan yang dilakukan kader sudah aktif dan merata yang ditunjang oleh faktor pendidikan kader posyandu yaitu SLTA serta pekerjaan kader sebagai ibu rumah tangga sehingga mempunyai waktu luang yang banyak. Menurut tingkat pendidikan yang tinggi akan lebih memiliki wawasan dan ketrampilan yang lebibaik sehingga akan lebih mampu memberikan bimbingan kepada masyarakat, dan semakin banyak waktu luang semakin baik pula pekerjaan yang dilaksanakan oleh seorang kader posyandu. Melalui bimbingan yang diterima kader mengakibatkan kader mempunyai banyak pengalaman dan dikenal pengunjung sehingga kurang komunikasi pada waktu melakukan kunjungan ke rumah. Oleh karena itu, dalam meningkatkan bimbingan tetap diperlukan adanya dukungan dari berbagai sektor untuk diadakan pelatihan kader yang dapat meningkatkan kemampuan kader dalam memberikan bimbingan kepada masyarakat.

Penelitian sebelumnya yang berhubungan dengan pembinaan menyimpulkan bahwa karakteristik, pembinaan kader dan perilaku kader memiliki pengaruh yang signifikan terhadap peran kader posyandu. Menurut pembinaan puskesmas dari 4 variabel yang diteliti yaitu pemeriksaan pencatatan dan pelaporan, kunjungan ke lokasi posyandu, rapat posyandu dan pelatihan kader, hanya satu variabel yaitu pemeriksaan pencatatan dan pelaporan yang berpengaruh terhadap keaktifan kader posyandu.

Kepatuhan Ibu Membawa Balita Ke Posyandu Di Desa Gasaribu Kecamatan Laguboti Kabupaten Toba Samosir

Berdasarkan analisa data menunjukkan kepatuhan ibu membawa balita ke posyandu di Desa Gasaribu Kecamatan Laguboti Kabupaten Toba Samosir sebanyak 35 orang $(70 \%)$ patuh membawa balita ke 
Posyandu dan 15 orang (.30\%) tidak patuh membawa balita ke Posyandu. Bimbingan aktif oleh kader posyandu menunjukkan bahwa yang terbanyak ibu balita patuh mengunjungi Posyandu sebanyak 70\%. Akan tetapi masih terdapat 30\% ibu balita yang tidak patuh mengunjungi Posyandu. Ketidakpatuhan ini disebabkan adanya faktor ibu balita yang sibuk bekerja (selain ibu rumah tangga), karena berkerja sebagai PNS dan pegawai Swasta, kemudian ibu tidak tahu jadwal posyandu akibat kurang mendapatkan informasi, dan jarak tempuh ke Posyandu.

Kepatuhan kunjungan ibu balita ke Posyandu dipengaruhi oleh faktor waktu luang ibu dan pendapatan keluarga. Untuk meningkatkan kepatuhan kunjungan ibu balita ke Posyandu diharapkan ibu balita dapat menyediakan waktu untuk berpartisipasi aktif datang ke Posyandu pada hari buka posyandu untuk memperoleh bimbingan dari kader sehingga ibu balita mendapatkan informasi tentang kesehatan balitanya. Selain itu, kader dan masyarakat dapat menentukan jadwal kegiatan posyandu bersama-sama dan memilih lokasi posyandu yang tepat. Semakin ibu balita tidak patuh datang ke Posyandu tiap bulan semakin sedikit informasi yang didapat tentang kesehatan balitanya yang menyebabkan status kesehatan anak tidak terpantau sehingga status kesehatan anak tidak optimal.

Kepatuhan adalah istilah yang berarti patuh pada hukum karena hukum dianggap suatu keharusan, sedangkan komitmen normatif melalui legitimasi (normative commitment through legitimacy) berarti patuh pada peraturan karena otoritas penyusun hukum yang memiliki hak untuk mendikte perilaku (Sulistyo, 2010). Tidak hanya tingkat pengetahuan responden yang dapat mempengaruhi kepatuhan ibu untuk datang ke posyandu, tetapi ada 6 faktor lain yang dapat mempengaruhi ibu untuk datang ke posyandu. Faktor pertama adalah adanya kepentingan yang mendesak. Kepentingan yang mendesak ini berarti orang melakukan sesuatu pada saat tertentu karena kepentingan yang mendesak, hal ini memungkinkan ibu berkunjung ke posyandu jika ada kepentingan yang mendesak saja kalau tidak ada hal yang mendesak ibu tidak akan berkunjung ke posyandu. Misalnya anak balita sedang sakit diare dan sedang tidak punya uang jika anaknya tidak diberobatkan maka keadaan anaknya semakin memburuk sehingga ibu terpaksa datang ke posyandu. Faktor yang kedua adalah memuaskan keinginan atau keinginan ibu untuk datang ke posayandu. Memuaskan keinginan atau keinginan ibu untuk datang ke posyandu, ini berarti jika ibu berkeinginan datang ke posyandu ibu akan berkunjung ke posyandu untuk memantau tumbuh kembang balitanya. Sehingga ibu patuh atau datang ke posyandu kare na ibu mempunyai keinginan atau tertarik untuk datang ke posyandu. Faktor yang ketiga adalah kesadaran diri. Kesadaran diri, diartikan juga sebagai hati nurani yang merupakan suara hati yang baik, jujur dan lurus. Kesadaran diri tidak mungkin dipaksakan oleh apapun. Kesadaran diri ini berarti jika ibu mempunyai rasa kesadaran diri bahwa posyandu itu penting atau mempunyai manfaat untuk anak dan dirinya, maka ibu akan berkunjung ke posyandu, sehingga tingkat kepatuhan ibu yang datang ke posyandu tinggi. Faktor yang ke empat adalah keterbukaan. Keterbukaan, keterbukaan diartikan sebagai suatu sikap dan perasaan untuk selalu bertoleransi serta mengungkapkan katakata dengan sejujurnya sebagai landasan untuk berkomunikasi. Dengan demikian keterbukaan berkaitan erat dengan komunikasi dan hubungan antar manusia. Jika ibu memiliki rasa keterbukaan maka ibu dapat mengungkapkan pendapatnya terhadap kegiatan posyandu sehingga jika ibu merasa sesuai dengan kegiatan posyandu maka ibu akan datang ke posyandu. Faktor yang kelima adalah rasa tanggung jawab ibu terhadap posyandu. Tanggung jawab adalah berkewajiban menanggung, memikul segala akibatnya. Tanggung jawab sering mengalahan kepatuhan dan kesadaran diri sendiri, ini berarti jika ibu mempunyai rasa tanggung jawab terhadap posyandu tingkat kedatangan atau kepatuhan ibu yang berkunjung ke posyandu tinggi. Faktor yang keenam adalah kesenangan atau kepercayaan 
terhadap posyandu. Kesenangan atau kepercayaan, hal-hal yang menyangkut kesenangan, cinta dan kepercayaan yang mengalahkan kesadaran atau kepatuhan seseorang. Kepercayaan berhubungan erat dengan harapan, karena dalam kepercayaan terdapat banyak harapan yang menyangkut masalah masa depan manusia. Ini berarti jika ibu mempunyai rasa kesenangan atau percaya terhadap posyandu ibu akan berkunjung ke posyandu. Ini bisa dikarenakan ibu mempunyai harapan terhadap kegiatan yang ada di posyandu.

Hubungan Kualitas Pelayanan Dengan Kepatuhan Ibu Datang Ke Posyandu Di Desa Gasaribu Kecamatan Laguboti Kabupaten Toba Samosir

Hubungan kualitas pelayanan dengan kepatuhan ibu datang ke Posyandu di Desa Gasaribu Kecamatan Laguboti Kabupaten Toba Samosir dengan hasil uji chi square dengan nilai $\mathrm{p}=0.005$ yang berarti ada Hubungan kualitas pelayanan dengan kepatuhan ibu datang ke Posyandu di Desa Gasaribu Kecamatan Laguboti Kabupaten Toba Samosir. Penelitian ini menggunakan tingkat kepercayaan 5\% dan kekuatan uji $95 \%$.

Penelitian yang meneliti tentang pemberdayaan kader posyandu dalam upaya meningkatkan kualitas program gizi, menunjukkan bahwa adanya pemberdayaan tersebut terjadi peningkatan pengetahuan kader sehingga kader mampu melakukan bimbingan. Bimbingan tersebut dapat meningkatkan partisipasi masyarakat dalam ikut serta dalam Posyandu (Widiastuti, 2011) yang meneliti tentang pemanfaatan pelayanan posyandu menunjukkan bahwa pengetahuan kader, motivasi kader, dan faktor pekerjaan ibu balita berhubungan positif dengan tingkat pemanfaatan penimbangan balita di Posyandu. Ini berarti pengetahuan kader berperan pada partisipasi masyarakat. Penelitian ini sesuai dengan hipotesis dan teori yang dikemukakan bahwa kepatuhan kunjungan ke Posyandu dapat dipengaruhi oleh bimbingan kader posyandu. Dengan adanya bimbingan secara aktif dari kader maka ibu balita akan cenderung berperilaku ke arah yang positif yaitu patuh berkunjung ke Posyandu pada tiap bulannya.

Menurut penelitian Astinah, dkk., (2013), agar seseorang bertindak untuk mengobati atau mencegah penyakitnya maka ia harus merasakan bahwa ia rentan terhadap penyakit tersebut. Apabila seseorang merasa tidak rentan terhadap penyakit tersebut, maka perlu diberikan rangsangan yang lebih intensif agar dia juga mencetuskan respon yang diinginkan yaitu membawa balitanya secara rutin ke posyandu. Kerentanan yang dirasakan rendah terhadap suatu penyakit dapat disebabkan karena minimnya pengetahuan tentang bahaya penyakit tersebut. Sehingga apabila dikaitkan dengan penelitian ini, ibu yang tidak membawa balitanya sama sekali atau tidak secara rutin membawa balitanya ke posyandu memiliki pengetahuan yang rendah terhadap risiko penyakit tersebut, sehingga sangat penting untuk sosialisasi pentingnya membawa balita secara rutin ke posyandu. Penelitian Khadijah, S. (2011), menemukan bahwa terdapat hubungan antara pengetahuan ibu balita dengan perilaku kunjungan ibu ke posyandu. Secara keseluruhan ibu yang mempunyai tingkat pengetahuan baik, ratarata mempunyai tingkat perilaku berkunjung ke posyandu yang baik. Penelitian lain oleh Suhat dan Hasanah pada tahun 2014 ditemukan bahwa terdapat hubungan antara pengetahuan ibu dengan tindakan ibu untuk membawa anaknya ke posyandu.

Masih banyak ibu balita yang tidak patuh berkunjung ke Posyandu dikarenakan kurangnya penyebaran informasi dari kader posyandu. Kurangnya penyebaran informasi sangat erat hubungannya dengan pelaksanaan bimbingan kader posyandu. Oleh karena itu, diperlukan adanya pelatihan kader agar kader dapat memberikan bimbingan dan meningkatkan ketrampilannya dalam menggerakkan masyarakat untuk datang ke Posyandu, kader bersama masyarakat dapat menentukan jadwal kegiatan posyandu, dan memilih lokasi yang tepat. Selain itu, ibu balita dapat berpartisipasi aktif baik di dalam pelayanan posyandu maupun di luar jadwal 
pelayanan posyandu agar mendapatkan informasi tentang kesehatan balitanya

\section{KESIMPULAN}

Responden berdasarkan berdasarkan umur, pendidikan dan pekerjaan, yakni responden mayoritas 26-35 tahun sebanyak 30 orang $(60 \%)$, 36-45 tahun sebanyak 18 (36\%), pendidikan SMA sebanyak 11 orang (22\%), D3 sebanyak 32 orang (64\%), sarjana 7 orang (14\%) dan pekerjaan mayoritas adalah Ibu rumah tangga sebanyak 30 orang $(60 \%)$ dan pegawai swasta 15 orang $(30 \%)$. Kualitas pelayanan kader di posyandu di desa Gasaribu Kecamatan Laguboti Kabupaten Toba Samosir menunjukkan bahwa $100 \%$ kader memberikan kualitas pelayanan baik.

Kepatuhan ibu membawa balita ke posyandu di desa Gasaribu Kecamatan Laguboti Kabupaten Toba Samosir sebanyak 35 orang $(70 \%)$ patuh membawa balita ke Posyandu dan 15 orang (30\%) tidak patuh karena ibu sibuk dengan pekerjaan, kurang informasi tentang jadwal informasi Posyandu dan jauh dari pelayanan posyandu.

Hubungan kualitas pelayanan dengan kepatuhan ibu datang ke Posyandu di desa Gasaribu Kecamatan Laguboti Kabupaten Toba Samosir dengan hasil uji chi square dengan nilai $\mathrm{p}$ : 0.005 yang berarti ada Hubungan kualitas pelayanan dengan kepatuhan ibu datang ke Posyandu di desa Gasaribu Kecamatan Laguboti Kabupaten Toba Samosir.

\section{SARAN}

1. Bagi pelayanan Puskemas dapat meningkatkan program kegiatan posyandu dengan cara mengadakan pelatihan kader dan dukungan dari berbagai sektor agar kader dapat memberikan bimbingan dan meningkatkan ketrampilannya dalam menggerakkan masyarakat sehingga kegiatan posyandu dapat berlangsung dan ada peningkatan kunjungan ibu balita ke Posyandu.

2. Bagi para peneliti selanjutnya, disarankan untuk mengambil data primer yaitu langsung dari ibu yang mempunyai balita serta meneliti faktor-faktor lain yang berhubungan dengan kepatuhan kunjungan ibu balita ke Posyandu

3. Bagi Posyandu mempertahankan kader yang telah bekerja dengan baik yang cepat dan tepat, serta lebih meningkatkan lagi pelayanannya khususnya di bidang kualitas pelayanan kader.

\section{DAFTAR PUSTAKA}

Departemen Kesehatan RI. 2009. Sistem Kesehatan Nasional. Jakarta: Depkes RI.

Fitrianto, B.G. (2015). Hubungan Keaktifan Penyuluhan Oleh Kader Posyandu dengan Cakupan Imunisasi Lengkap pada Bayi di Desa Arjasa dan Desa Candijati Kecamatan. Arjasa Kabupaten. Jember. Fakultas Ilmu Kesehatan Universitas Muhammadiyah Jember.

Khadijah, S. (2011). Faktor-faktor yang Mempengaruhi Kunjungan Ibu yang Mempunyai Balita 0-5 Tahun Ke Posyandu di Kelurahan Lubuk Tanjung Wilayah Kerja Puskesmas Perumnas Kota Lubuklinggau.

Kemenkes. (2015). Rencana Strategis Kementerian Kesehatan Tahun 20152019. Jakarta: Kementerian Kesehatan RI

Hardiana, M.P. (2014). Hubungan Pelaksanaan Pelayanan Posyandu dengan Motivasi Ibu untuk Membawa Balita Ke Posyandu Seroja di Desa Tanjung Kamal Kecamatan Mangaran Kabupaten Situbondo. Fakultas Ilmu Kesehatan Universitas Muhammadiyah Jember.

Hidayati, N. (2010). Faktor-faktor yang Berhubungan dengan Partisipasi Ibu Balita Ke Posyandu di Kelurahan Rempoa Kecamatan Ciputat Timur Kota Tangerang Selatan. Fakultas Ilmu Kedokteran dan Ilmu Kesehatan.

Irawati, A. 2001. Kajian Pelaksanaan Revitalisasi Posyandu Pada Masyarakat Nelayan dan Petani Di Propinsi Jawa Barat. Diunduh pada 
tanggal 10 Juni 2011, dari www.litbang.depkes.go.id

Mubarak, W., \& Cahyatin. (2009). Ilmu Kesehatan Masyarakat: Teori dan Aplikasi. Jakarta: Salemba Medika.

Sari, Nia. (2015). Bimbingan Kader Posyandu dengan Kepatuhan Kunjungan Ibu Balita di Posyandu. Fakultas Keperawatan Universitas katolik Widya Mandala Surabaya.

Suhat dan Hasanah. (2014). Faktor-faktor yang Berhubungan dengan Keaktifan Kader dalam Kegiatan Posyandu (Studi di Puskesmas Palasari Kabupaten Subang).

Widiastuti, I. dkk. (2011). Pemanfataan Pelayanan Posyandu Di Kota Denpasar. WPS, No. 15 Juli 2006, first draft : 1-17. Diunduh pada tanggal 10 Juni 2011, dari http://lrckmpk.ugm.ac.id. 